European Department and

Middle East and Central Asia Department

\title{
The Spillover Effects of Russia's Economic Slowdown on Neighboring Countries
}

Prepared by Ara Stepanyan and Agustin Roitman (EUR), and Gohar Minasyan, Dragana Ostojic, and Natan Epstein (MCD) 
Copyright $\odot 2015$

International Monetary Fund

\section{Catalog-in-Publication Data}

The Spillover Effects of Russia's Economic Slowdown on Neighboring Countries / Prepared by Ara Stepanyan and Agustin Roitman (EUR), and Gohar Minasyan, Dragana Ostojic, and Natan Epstein (MCD). - Washington, D.C.: International Monetary Fund, 2015.

$$
\text { pages ; } \mathrm{cm}-\text { (report) }
$$

Includes bibliographical references.

ISBN: $[\ldots .$.

1. Spillover Effects 2. Monetary Policy 3. Emerging Markets 4. Exchange rates I. Stepanyan, Ara, Agustin Roitman, Gohar Minasyan, Dragana Ostojic, and Natan Epstein. II. International Monetary Fund. IV. Title: The Spillover Effects of Russia's Economic Slowdown on Neighboring Countries

ISBN: 978-1-51357-134-8 (paper)

This report presents research by IMF staff on issues of policy interest. The views expressed in this paper are those of the author(s) and do not necessarily represent the views of the IMF, its Executive Board, or IMF management.

Publication orders may be placed online, by fax, or through the mail: International Monetary Fund, Publication Services

P.O. Box 92780, Washington, DC 20090, U.S.A.

Tel. (202) 623-7430 Fax: (202) 623-7201

E-mail: publications@imf.org

www.imfbookstore.org www.elibrary.imf.org 


\section{Acknowledgments}

This paper was prepared by Ara Stepanyan and Agustin Roitman (EUR) and Gohar Minasyan, Dragana Ostojic, and Natan Epstein (MCD). We are grateful to the support from Gilda OrdonezBaric, Xuan Tu (EUR), and Soledad Feal-Zubimendi (MCD). 


\section{Contents}

1. Introduction

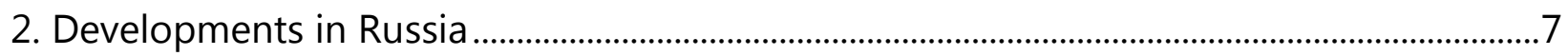

3. Channels of Spillovers to Neighboring Countries ................................................................. 10

Trade Channel................................................................................................................... 10

Remittances Channel....................................................................................................... 11

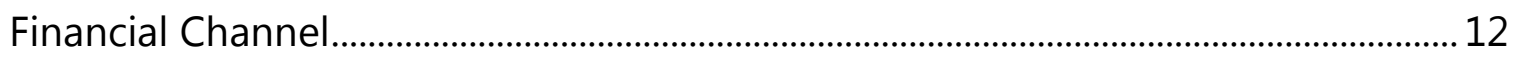

4. Impact So Far on the Affected Countries and Potential Further Shock............................. 15

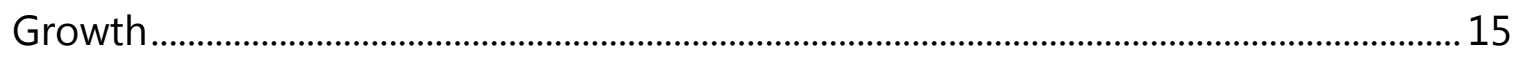

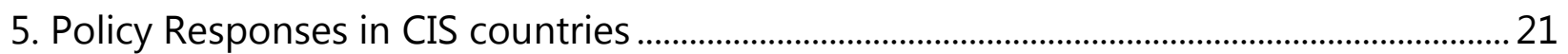

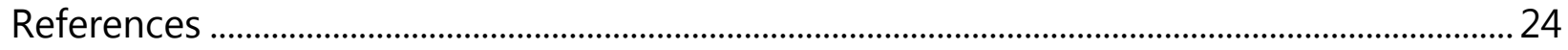

\section{Box}

1. Simulation of Impact of a Downside Scenario for Russia .....................................................20

\section{Figures}

1. Europe and CCA Links with Russia, 2014 (or the latest available) ......................................... 14

2. Exchange Rate and Sovereign Spreads, 2014-2015 .................................................................. 17

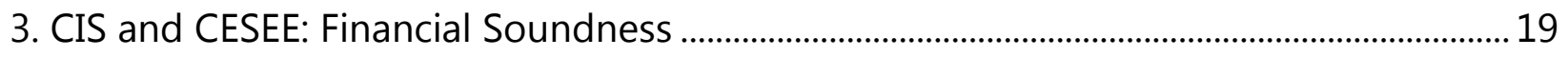

4. Fiscal Response in CIS countries .......................................................................................... 22 


\section{Introduction}

In the face of sharply lower oil prices and geopolitical tensions and sanctions, economic activity in Russia decelerated in late 2014, resulting in negative spillovers on Commonwealth of Independent States (CIS) ${ }^{1}$ and, to a lesser extent, on Baltic countries. The spillovers to eastern Europe have been limited. The degree of impact is commensurate with the level of these countries' trade, remittances, and foreign direct investment (FDI) links with Russia. So far, policy action by the affected countries has focused on mitigating the immediate consequences of spillovers.

Falling oil prices and Western sanctions are pushing the Russian economy into recession. Russia saw a large increase in risk premiums and capital outflows, which resulted in more than 65 percent depreciation in the national currency against the U.S. dollar between June and December 2014.

\section{Given historical links and geographic proximity, developments in Russia will have} negative spillovers on the economies of CIS and Baltic countries. Trade, remittances, and FDI are the main channels of spillovers. Some eastern European countries also have sizable trade and financial links with Russia. In general, western Europe's trade and financial links with Russia on average are weaker (Finland being a notable exception). The main link is through energy imports from Russia, which exceeds 5 percent of total energy consumption for several western European countries. Henceforth, the note will focus on spillovers to CIS, Baltic, and eastern European countries.

Russia's growth slowdown has had major adverse effects on CIS economies and to some extent on Baltic countries. Currencies of most of the CIS countries weakened sharply against the U.S. dollar, following the ruble's depreciation. Pass-through from exchange rate

\footnotetext{
${ }^{1}$ Georgia and Turkmenistan are not members of the CIS, but they are included in this group because of their geographic proximity and similarity of economic structure.
} 
depreciation intensified inflationary pressures in most CIS countries. In addition, sovereign spreads have significantly widened in some CIS countries, which was partially a result of spillovers from Russia. Expected recession in Russia in 2015 has contributed to significant growth revisions in the CIS and to a lesser extent in Baltic countries.

So far, policy responses by affected countries have aimed at addressing the shortterm impact of spillovers. In most of these countries, monetary policy was tightened, while fiscal policy was loosened. Despite foreign exchange (FX) interventions by central banks, national currencies have depreciated or have been devalued in nearly all CIS countries. 


\section{Developments in Russia}

In 2014 the Russian economy was hit by sanctions and rapidly falling oil prices. These shocks led to significant balance of payment pressures with a surge in capital outflows and depreciating exchange rate. Consequently, akin to a sudden stop, external financing conditions worsened substantially.

The economic outlook for 2015-16 is weak, as sanctions and oil price shocks are expected to persist.

- Growth and inflation: Sanctions and a sharp drop in oil prices are expected to cause Russia's GDP to contract by 3.4 percent in 2015 . The fall in oil prices will significantly affect real incomes and investment prospects, hence taking a toll on domestic demand. Net capital outflows are likely to remain elevated in 2015 due to Russia's limited access to international capital markets. This will add to pre-existing structural bottlenecks and sanctions imposed during 2014, resulting in a recession in 2015. Since December last year oil prices have recovered somewhat supporting the ruble, which has appreciated by about 4 percent against the dollar in first half of 2015. The Russian economy contracted by 1.9 percent (yearover-year) in the first quarter of 2015, mainly reflecting a decline of household real incomes. However, the decline in industrial production was smaller than expected partly supported by a weaker ruble. Inflation should decline rapidly over the next two years. While the oil price drop and sanctions impact potential output, the cyclical downturn will open a small output gap in 2015-16. This, together with the dissipating effect from the exchange rate passthrough, partial public wage indexation in the 2015 budget, and the recent ruble appreciation, will set the stage for inflation to fall to 12.5 percent at end-2015 and 7.8 percent in 2016. Given the long-lasting nature of these shocks and pre-existing structural challenges, Russia's long-term growth projection was reduced by 2 percentage points in 2015 relative to the 2013 projections.

- External adjustment: The external sector adjustment is underway. In the first quarter of 2015, imports' compression reflects both weak domestic demand and expenditure switching due to the ruble depreciation. Exports values fell with global oil prices but volumes have 
remained broadly constant. External deleveraging continued in the face of limited market access, with external debt falling to USD560 billion at end-2015Q1 from USD730 billion at end-2013. These developments would have major adverse spillovers on economies with strong economic links with Russia.

The authorities' macroeconomic policy response stabilized the economy. Monetary policy was tightened and exchange rate flexibility was brought forward amidst market turbulence. Measures to support financial stability were also introduced. All these policy steps helped contain the balance of payment and banking sector pressures.

- Monetary tightening. The Central Bank of Russia (CBR) started increasing interest rates at a measured pace in early 2014, lifting the policy rate from 5.5 percent to 9.5 percent while relaxing the exchange rate band from the second half of the year. However, when market pressures intensified, the CBR floated the ruble in November to facilitate a more rapid adjustment to external shocks and curb reserve losses. Subsequently, the central bank raised the policy rate to 17 percent, including by 650 basis points on December 16th. The latter hike aimed at limiting financial stability risks following the large currency depreciation and volatility in December. In addition, the CBR expanded its FX liquidity provision and launched a package to support the banking system. The CBR started to withdraw the emergency policy rate increases in early 2015 , as financial market conditions, the exchange rate, and bank deposits stabilized.

- Stabilizing the banking sector. In December 2014, the CBR introduced temporary regulatory forbearance on loan classification, provisioning, and valuation accounting amid ruble depreciation and market volatility. ${ }^{2}$ The measures were appropriately combined with intensified supervision and their elimination will start in July 2015. To shore up banks, the government launched a Rub 1 trillion bank capital support program (1.5 percent of GDP) together with the use of up to Rub 400 billion from the National Wealth Fund (NWF). ${ }^{3}$ Twenty-seven large banks, selected sanctioned banks, and top regional lenders qualify for the support. In exchange for public funds, the banks must comply with CBR's prudential

\footnotetext{
${ }^{2}$ While regulatory forbearance could cushion the adverse impact of the shock on banks in the short run, it should be reversed once conditions normalized.

${ }^{3}$ The federal government program has subsequently been reduced to Rub 830 billion, as estimates for capital support have been reduced. Recent CBR stress tests suggest that the government support for all the large eligible banks is sufficient to cover loan-loss provisioning and market losses under an adverse scenario.
} 
requirements, raise their own funds equal to at least half of the government support (with an exception made for (partly) state-owned banks), increase lending by 1 percent per month for three years, and commit to not raising management salaries or the overall wage bill for three years. Finally, the authorities refrained from the use of capital controls.

- Limited fiscal stimulus. The government introduced an anti-crisis plan, including a 2 percent of GDP bank capital support program, and revised its 2015 budget to reallocate spending to priority sectors. Spending was reallocated to priority areas such as support to the manufacturing sector, and social payments, while some programs were cut by 10 percent and public wages were partially indexed to inflation. The budget also includes limited tax cuts (about 0.2 percent of GDP). Additional measures include budget credit to regions, federal credit guarantees, and use of the NWF to support systemically important enterprises and banks.

Significant risks and uncertainty remain, but Russia has large buffers. A possible intensification of geopolitical tensions would further dampen the outlook and increase balance of payment pressures. Lower oil prices, higher uncertainty, and tighter financing conditions would further dampen activity. In addition, should the authorities pursue inward-looking policies or increase the role of the state in the economy, the positive effect from a more competitive exchange rate would likely be limited. Although most corporations have enough cash on hand to finance their external debt coming due and have natural hedges due to energy exports, deleveraging would entail reducing investment, which if sustained would further affect potential output. However, against the risks to the balance of payments, Russia has a net positive international investment position (18 percent of GDP), a sizable current account surplus of 4 percent of GDP, low public debt, and no need to access international markets for government financing due to the Reserve Fund (RF) buffer. ${ }^{4}$ Moreover, the CBR's international reserves remain ample and balance sheet currency mismatches are low. Thus, existing buffers reduce the likelihood of a systemic event.

\footnotetext{
${ }^{4}$ The 2015 budget assumes gross financing from the RF, reducing considerably fiscal buffers for the future.
} 


\section{Channels of Spillovers to Neighboring Countries}

Trade and remittances are the main channels of outward spillovers from Russia on neighboring countries (see Figure 1). Trade channel is particularly prominent in CIS and Baltic countries, given their historical links and geographic proximity, while remittances channel is important mainly for CIS countries. Trade links with Russia are generally weaker in Central and eastern Europe (CEE), though for some countries trade exposure is still considerable. In addition, indirect spillovers through confidence effects and common investor linkages could be substantial, which is difficult to quantify. FDI is another important channel of spillovers from Russia, which is mainly important for CIS and Baltic and some eastern European countries. Other financial links are relevant only for a few countries.

\section{Trade Channel}

- Export of goods and services to Russia: Russia is an important export destination for a number of CIS and Baltic countries. Belarus, Lithuania, and Turkmenistan have the largest exposure with exports to Russia exceeding 10 percent of GDP. However, it should be noted that a sizable share of exports from the Baltics to Russia is re-exports of goods produced elsewhere, thus domestic economies in Baltic countries are not as sensitive to the developments in Russia as total export numbers may suggest. CEE countries with export to Russia between 2 to 5 percent of GDP include the Czech Republic, Hungary, Serbia, the Slovak Republic, and Slovenia. For most other eastern European countries, exports to Russia are below 1 percent of GDP. While direct trade links between CEE and Russia are limited, 
indirect spillovers through confidence effects could be substantial. ${ }^{1}$ For a number of Caucasus and Central Asia (CCA) countries, ${ }^{2}$ Russia is an important niche market. For example, exports to Russia account for about half of non-oil exports for Azerbaijan; for Armenia, exports of food products to Russia have been a source of dynamism in the economy; and about a quarter of Moldova's agricultural exports are destined to Russia. Turkmenistan and Uzbekistan export gas to Russia but have been increasingly diversifying toward other markets, primarily China. Russia accounts for about a quarter of Turkmenistan's gas exports (down from around 70 percent during the global financial crisis). Traditional trade links and preferential agreements (for example, the Eurasian Economic Union) with Russia may limit the capacity of some countries to diversify export destinations away from Russia.

- Imports from Russia: Imports from Russia, including energy imports, constitute more than 5 percent of GDP for most CIS and some CEE countries. For a number of countries (Armenia, Belarus, Hungary, Latvia, Lithuania, Moldova, the Slovak Republic, and Ukraine), energy imports from Russia exceed 20 percent of their total energy consumption. At the same time, some countries may not benefit from lower energy prices in the near term, since contracts on gas supply are usually long term, in some cases prices being fixed for several years.

\section{Remittances Channel}

Remittances are a key channel of transmission of shocks from Russia to CIS oil importers. CIS oil importers are among the most remittance dependent economies in the world. Remittances constitute about 45 percent of GDP in Tajikistan, 30 percent in the Kyrgyz Republic, 24 percent in Moldova, and 20 percent of GDP in Armenia as of 2014, with the bulk of these remittances originating from Russia. Remittances from Russia have grown substantially over the past decade

\footnotetext{
${ }^{1}$ For a discussion of the impact of geopolitical tensions on CESEE countries' confidence, see the October 2014 Central, Eastern, and Southeastern Europe Regional Economic Issues Update (IMF 2014a); “Europe's Russian Connections," a blog by IMF staff members (Husain, Ilyina, and Zeng 2014); and IMF staff reports for Article IV consultations for the Russian Federation (IMF 2014c), Poland (IMF 2014b), Hungary (IMF 2015b), and the Czech Republic (IMF 2015a).

${ }^{2}$ CCA countries comprise Armenia, Azerbaijan, Georgia, Kazakhstan, the Kyrgyz Republic, Tajikistan, Turkmenistan, and Uzbekistan.
} 
and appear to be closely correlated with the activity in Russia's non-tradable sector, where most of the migrant workers tend to work.

The non-tradable sector activity is, in turn, highly correlated with oil prices, very volatile, and is characterized by flexible labormarket arrangements. The large presence of migrant workers in Russia makes these countries vulnerable to risks of surges in unemployment and social tensions in case migrants are forced to return. While returning migrants can bring new skills

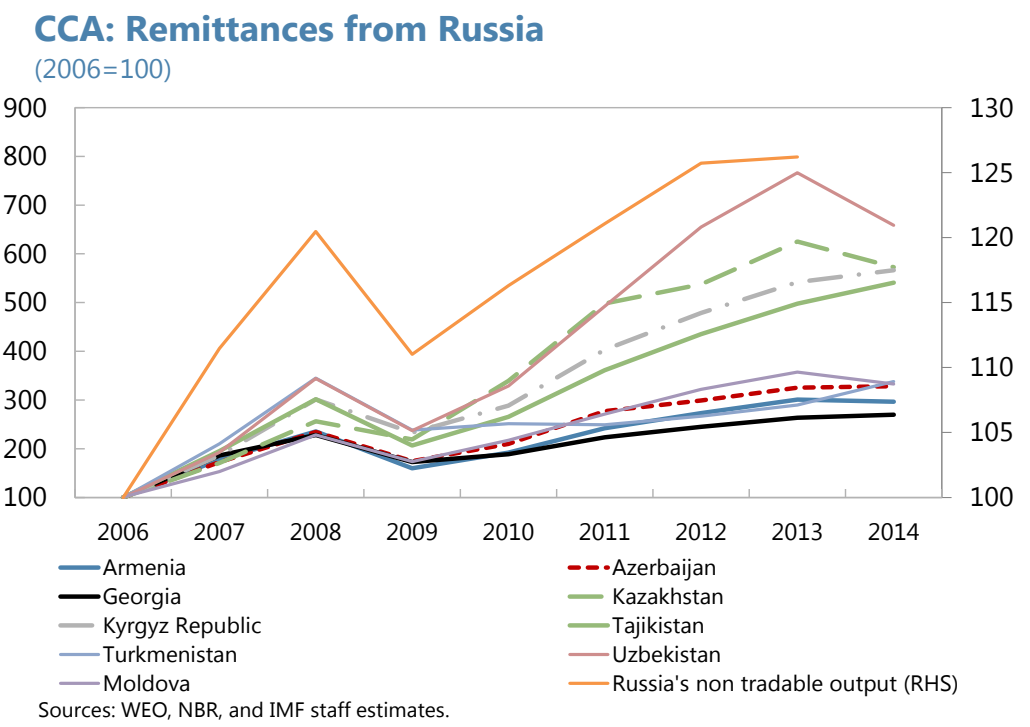
and contacts back to their countries, they create additional pressures on labor markets by increasing unemployment, putting downward pressures on wage levels, and increasing the need for social assistance.

\section{Financial Channel}

Spillovers via the financial system appear more limited. The direct spillovers would be mainly via changes in flows of FDI, and to a smaller degree via the banking system. Spillovers via asset markets and debt and equity flows are less pronounced and contained to a few countries. ${ }^{3}$

- Foreign Direct Investment from Russia: The stock of FDI from Russia exceeds 2 percent of GDP in many CIS and Baltic and some CEE countries, with Armenia, Bulgaria, Moldova, Montenegro, and Tajikistan receiving more than 5 percent of GDP in Russian FDI. FDI is an important vehicle for technology transfer and can be a driver of growth and domestic investment. The slowdown in Russia could decrease FDI flows, affecting long-term investment and growth prospects for these countries.

- Banking linkages: Direct cross-border lending from Russia is relatively small, though asset share of Russian banks is about 10 percent of banking system assets in a number of

\footnotetext{
${ }^{3}$ Bilateral portfolio flows between Russia and CESEE countries are limited to about 0.1 percent of GDP.
} 
countries. ${ }^{4}$ Latvia is the recipient of large non-resident deposits, equivalent to about 50 percent of total deposits, the lion's share of which is presumed of Russian origin. While there have been no disruptions so far, a possible reversal of these flows could be a source of risk. Bank claims on Russian residents are somewhat noticeable for Hungarian banks (more than 3.5 percent of GDP). ${ }^{5}$ Furthermore, Azerbaijani and Kazakh banks have subsidiaries in Russia, but their assets are relatively small (about 2 percent of home country's GDP). However, second-round effects of spillovers on the banking sectorpropagated by other channels in particular exchange rate and remittances, could be significant. Exchange rate movements in highly dollarized banking systems, and declining remittance income that is used to service loans, could undermine the debt repayment capacity of banking clients, and potentially, lead to an increase in nonperforming loans (NPLs), and thus cause problems in the banking sector. In addition, currency depreciation could give rise to a credit risk stemming from unhedged foreign currency borrowing.

\footnotetext{
${ }^{4}$ Sberbank has subsidiaries in Belarus, Bosnia and Herzegovina, Hungary, Kazakhstan, Turkey, and Ukraine; VTB bank has subsidiaries in Armenia, Azerbaijan, Georgia, Kazakhstan, Belarus, and Ukraine, and Gazprombank in Armenia and Belarus.

5 This is driven by the subsidiary of Hungarian OTP bank in Russia.
} 
Figure 1. Europe and CCA Links with Russia, 2014 (or the latest available)

\begin{tabular}{|c|c|c|c|c|c|c|c|c|}
\hline & Gas/Energy & $\begin{array}{l}\text { Imports from } \\
\text { Russia }\end{array}$ & Exports to Russia & $\begin{array}{l}\text { Remittances from } \\
\text { Russia }\end{array}$ & FDI from Russia & FDI in Russia & $\begin{array}{l}\text { Bank Claims in } \\
\text { Russia }\end{array}$ & $\begin{array}{c}\text { Assets of Russian } \\
\text { Banks } \\
\text { Subsidiaries and } \\
\text { Branches }\end{array}$ \\
\hline \multicolumn{9}{|c|}{ Commonwealth of Independent States } \\
\hline \multicolumn{9}{|l|}{ Armenia } \\
\hline \multicolumn{9}{|c|}{ Azerbaijan } \\
\hline \multicolumn{9}{|l|}{ Belarus } \\
\hline \multicolumn{9}{|l|}{ Georgia } \\
\hline \multicolumn{9}{|c|}{ Kazakhstan } \\
\hline \multicolumn{9}{|c|}{ Kyrgyz Republic } \\
\hline \multicolumn{9}{|l|}{ Moldova } \\
\hline \multicolumn{9}{|c|}{ Tajikistan } \\
\hline \multicolumn{9}{|c|}{ Turkmenistan* } \\
\hline \multicolumn{9}{|l|}{ Ukraine } \\
\hline \multicolumn{9}{|c|}{ Uzbekistan* } \\
\hline \multicolumn{9}{|c|}{ Baltic States } \\
\hline \multicolumn{9}{|c|}{ Estonia } \\
\hline \multicolumn{9}{|l|}{ Latvia } \\
\hline \multicolumn{9}{|c|}{ Lithuania } \\
\hline \multicolumn{9}{|c|}{ Central and Eastern Europe } \\
\hline \multicolumn{9}{|c|}{ Albania } \\
\hline \multicolumn{9}{|c|}{ Bosnia and Herzegoviı } \\
\hline \multicolumn{9}{|c|}{ Bulgaria } \\
\hline \multicolumn{9}{|l|}{ Croatia } \\
\hline \multicolumn{9}{|c|}{ Czech Republic } \\
\hline \multicolumn{9}{|c|}{ Hungary } \\
\hline \multicolumn{9}{|c|}{ Montenegro } \\
\hline \multicolumn{9}{|c|}{ Macedonia } \\
\hline \multicolumn{9}{|l|}{ Poland } \\
\hline \multicolumn{9}{|c|}{ Romania } \\
\hline \multicolumn{9}{|c|}{ Serbia } \\
\hline \multicolumn{9}{|c|}{ Slovak Republic } \\
\hline Slovenia & & & & & & & & \\
\hline Turkey & & & & & & & & \\
\hline
\end{tabular}

Notes: (*) Gas exports to Russia; Gas/energy imports from Russia are scaled by country's energy consumption; other variables are scaled by GDP. Turkmenistan is an associate member of the CIS; Georgia has been a member of the CIS during 1993-2009.

Sources: Eurostat; DOTS; BIS; and IMF staff estimates.

\begin{tabular}{|c|c|c|c|c|c|}
\hline For Gas/Energy & greater than 50 & between 20-50 & between $10-20$ & between 5-10 & less than 5 \\
\hline For other indicators & greater than 5 & between 2-5 & between $1-2$ & less than 1 & NA \\
\hline
\end{tabular}




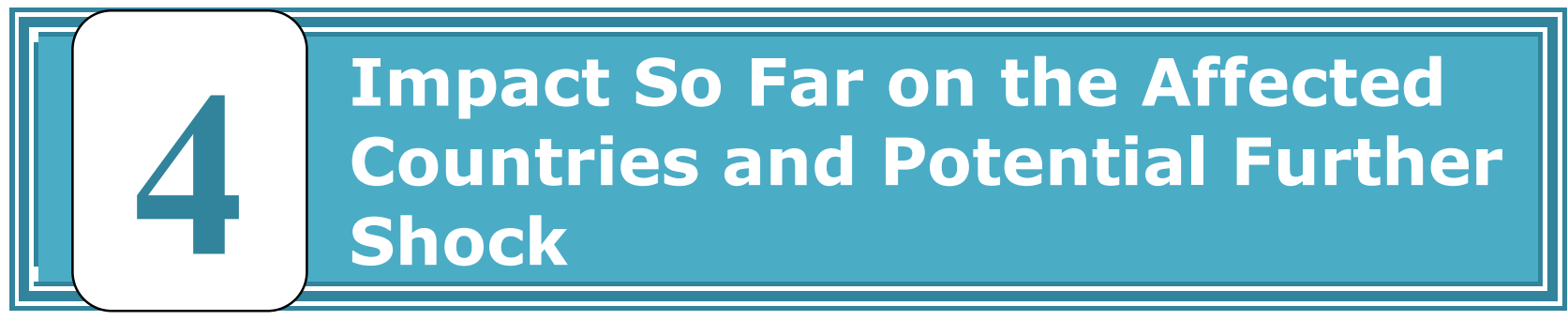

Given the aforementioned spillover channels and strong historical ties with individual countries, the slowdown in Russia-the largest economy in the region-has adverse effects on neighboring economies. As a result, growth in CIS countries has decelerated as well. In addition, exchange rates are weakening against the U.S. dollar, inflation is rising, and risks are building up in the financial systems of some countries.

\section{Growth}

\section{The negative spillovers contributed to sizable downward revisions to growth forecasts} across the CIS and to a lesser extent in Baltic economies (text chart). Direct spillovers from Russia played an important role in explaining output behavior in most of CIS countries during the 2008-09 global financial crisis as well as during the recent slowdown, as Russian and CIS business cycles tend to co-move. In particular, for CIS oil importers, adverse spillovers from Russia in 2015 account for more than 2.5 percentage points of downward growth revision relative to April 2014. For CIS oil

Revisions to Real GDP Growth, 2015

(WEO April vs. April 2014, percent)

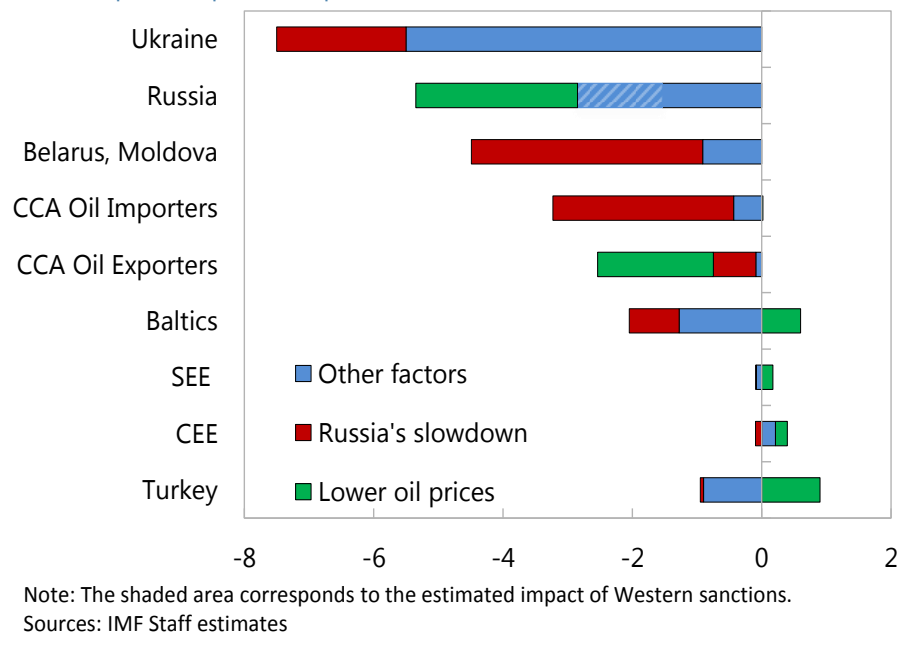
exporters and Baltics, negative spillovers from Russia contributed to around 1 percentage point downward revision in the growth forecast. In addition, slower secular growth in Russia will have negative implications for the medium-term outlook of CIS and Baltic countries. 


\section{Exchange rate and risk indicators}

\section{Currencies of most CIS countries depreciated (or were devalued) sharply against the} U.S. dollar following the ruble's depreciation, reflecting confidence effects and expected declines in foreign currency inflows from Russia (remittances, FDI, and exports). ${ }^{1}$ Countries with significant trade and remittance links to Russia experienced larger currency depreciation, reflecting expected deterioration in current account balances (see Figure 2). At the same time, most of the currencies appreciated against the ruble which led to real effective exchange rate appreciations. The rapid decline in oil prices has added to downward pressures on exchange rates of energy-exporting countries, due to weaker current account and fiscal positions. Sovereign spreads have widened significantly for some CIS countries reflecting the collapse in confidence since markets perceived these countries as the most vulnerable to spillovers from Russia.

\section{Inflation}

\section{Pass-through from exchange rate depreciations has been the main channel through which spillovers from Russia impacted inflation in CIS countries.}

Given that the majority of imports, even from Russia, are denominated in U.S. dollars, the depreciation of local currencies vis-à-vis the dollar has led to inflationary pressures despite appreciation of nominal effective exchange rates. This was a notable factor contributing to the inflation forecast revision for CIS oil importers. However, slowing growth and soft international food prices partly offset

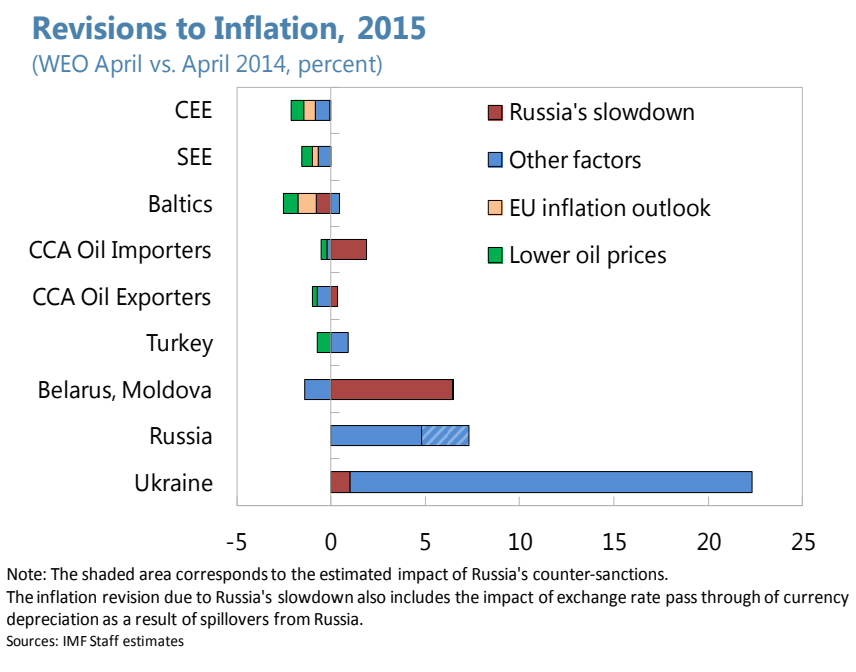
these inflationary pressures. The impact of declining oil prices on revisions of inflation forecasts has been limited so far to the Baltics, CEE, southeastern Europe (SEE), and Turkey, as the weight of gasoline and other fuels in the consumer price index (CPI) of CIS countries is typically small and regulated retail prices have been slow to adjust. The impact of import bans imposed by Russia on several agricultural and food products was another factor behind inflation developments. The impact was mainly felt in Baltic countries and Moldova. This has contributed to about 0.5 percentage points downward revision in the inflation forecast for 2015 relative to April 2014 forecasts for Baltics and Moldova.

\footnotetext{
${ }^{1}$ In the case of Ukraine, other idiosyncratic factors also played an important role.
} 
Figure 2. Exchange Rate and Sovereign Spreads, 2014-15
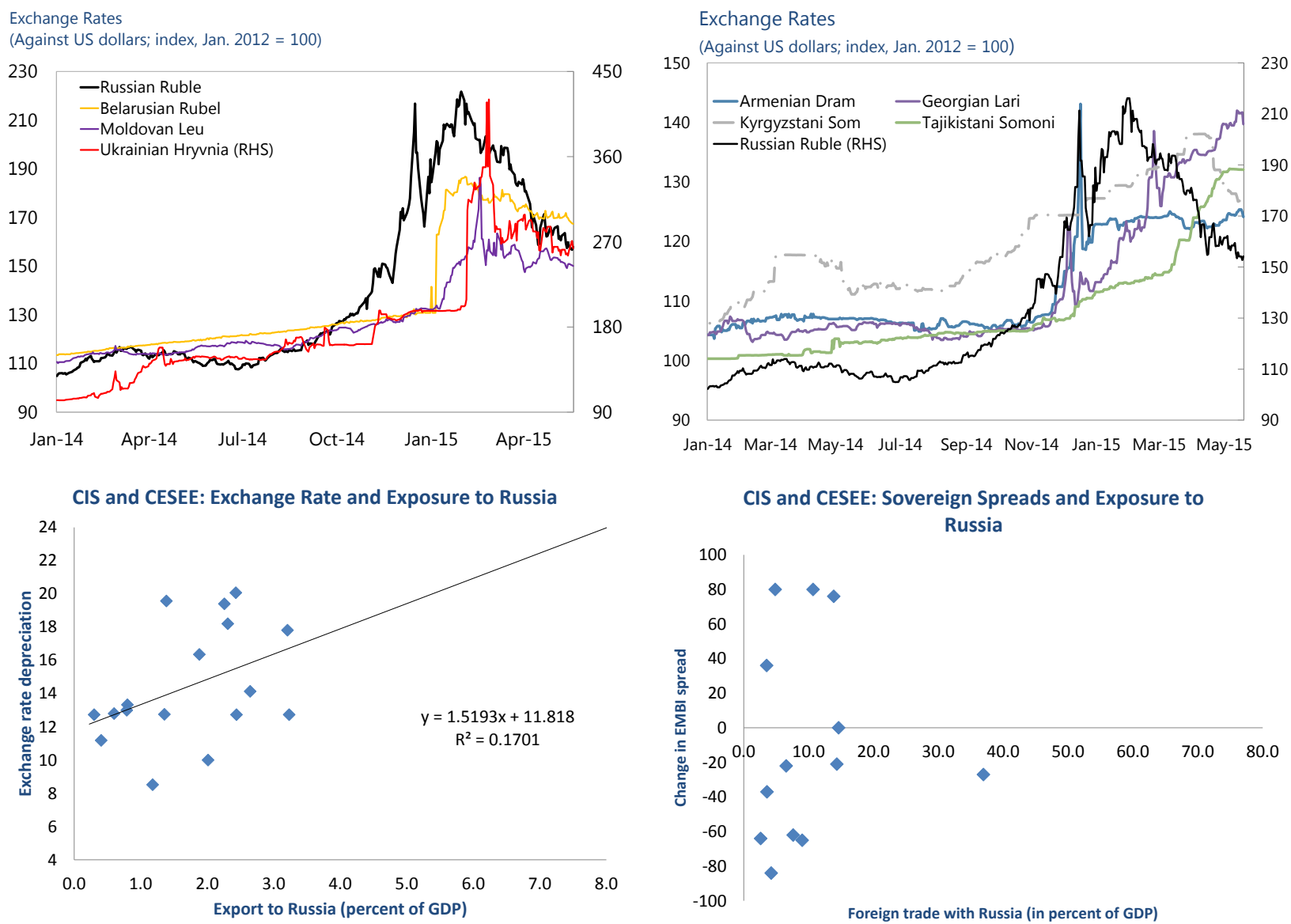

CIS and Central and Eastern Europe: Sovereign Spreads

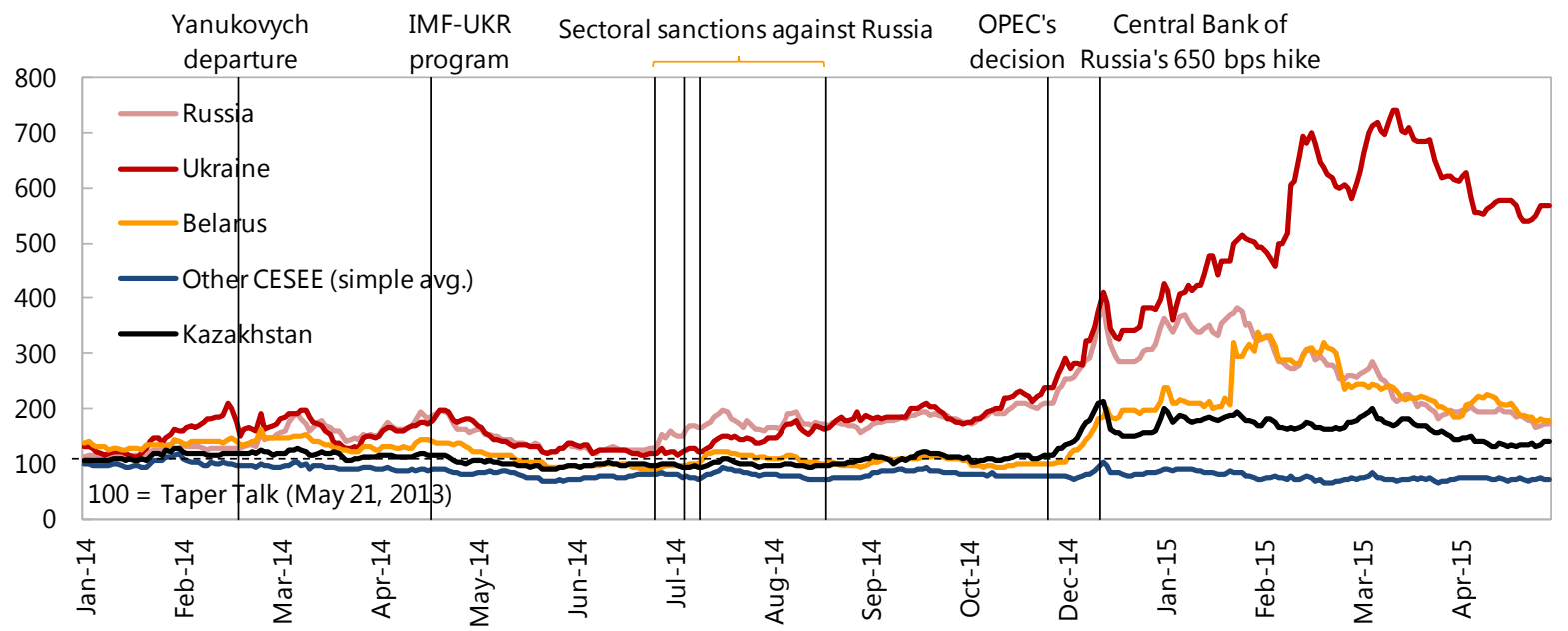

Sources: Bloomberg, L.P.; National Bank of Russia; and IMF staff estimates. 


\section{Financial stability}

Spillovers from Russia could have financial stability implications in affected countries, although so far impact has been limited. Exchange rate depreciations in highly dollarized economies could worsen balance sheets of banks and households reducing banks' profitability and asset quality. Already high and increasing levels of dollarization in the region, particularly in the CCA countries, where the share of dollar deposits is about 50-60 percent in most countries, points to weak confidence and expectations of further devaluations. In addition, the fall in demand and remittances, which in many countries are used to service debt could adversely affect banks' asset quality. Moreover, rising FX loan-todeposit ratios suggest a possibility of liquidity problems and currency mismatch. However, so far, there has not been a visible deterioration in banks' profitability and asset quality, which could be attributed to countries' relatively low financial sector exposure to Russia. Only Azerbaijan, Tajikistan, and Ukraine have experienced considerable deterioration in asset quality (see Figure 3). ${ }^{2}$ Profitability of banks has deteriorated somewhat in the CIS and Estonia with banking systems of Tajikistan and Ukraine recording losses. Still, NPLs are a backward-looking indicator and it will take time before the impact of these shocks would show up in higher NPLs. In this regard, having adequate buffers to deal with potential strains on banks' health is crucial. While capital adequacy in Baltic and CIS countries on average is above regulatory requirement and bank provisions account on average 50 percent of NPLs, there are notable differences across countries (Figure 3).

\section{Potential further shock}

\section{Downside risks for Russia are still present, and spillovers from a worsening of the current shock could affect the region, particularly CIS and Baltic countries (see Box 1).}

In the case of continued lack of access to capital markets, a further rise in sovereign and corporate spreads due to deposit flight and currency substitution, and a permanent loss in productivity owing to inward-looking policy responses, a downside scenario for Russia could materialize resulting in much sharper contraction of output in 2015 and 2016. The impact of an additional Russia growth shock on the region was simulated using a Flexible System of Global models, and output losses range from -3 percent in Armenia to -0.1 in Romania. The direct impact of Russia's more severe recession on the world GDP would be limited.

\footnotetext{
2 The deteriorating quality and weakening profitability of Ukrainian banks' assets stem from problems that can only to a limited extent be explained by spillovers from Russia.
} 
Figure 3. CIS and CESEE: Financial Soundness*
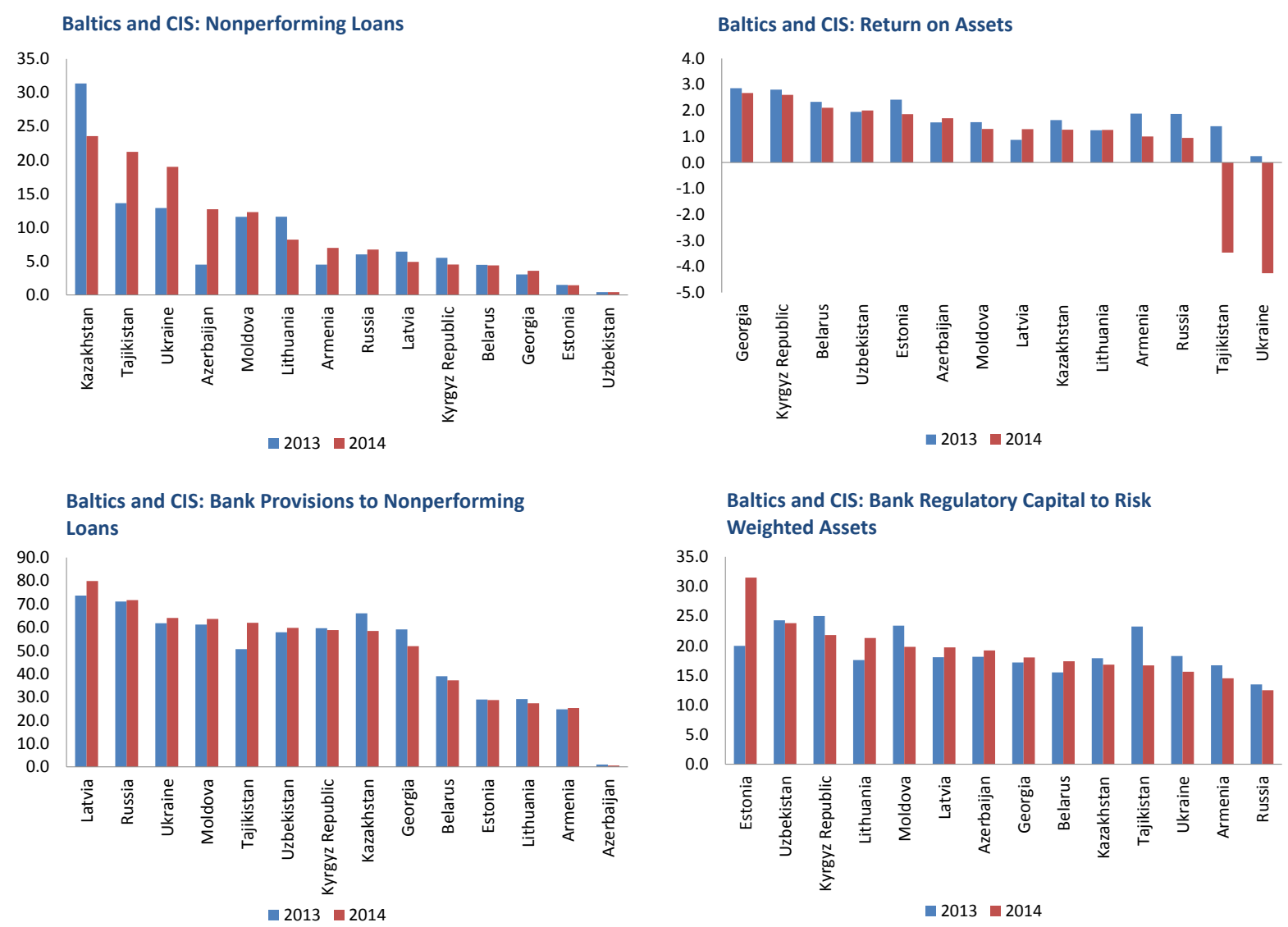

*The definitions of NPLs and provisioning vary considerably across countries, with some countries having more conservative definitions than others.

Sources: Global Financial Stability Report, April 2015; IMF staff estimates. 


\section{Box 1. Simulation of Impact of a Downside Scenario for Russia}

In a case of a more severe shock to the Russian economy, significant spillovers via trade, remittances and FDI would result in additional GDP losses for neighboring countries. The impact on the rest of the world would be minimal. If such a scenario materializes, deeper and faster policy responses are warranted to boost potential growth, secure fiscal and external sustainability, and ensure a sound financial sector.

A downside scenario for Russia: Additional balance of payments pressures emerge as a result of lack of capital market access and weaker confidence. The ruble depreciates as a result of additional capital outflows and inflation increases further. Moreover, deposit flight and currency substitution would put pressure on banks' balance sheets, and sovereign and corporate spreads would rise. This scenario would require a significant tightening of monetary policy and limit fiscal space. Inward-looking policy responses would result in a larger government presence in the economy (including the banking system) and less competition giving rise to a permanent loss in productivity. In the adverse scenario, GDP could fall by an additional 4 percent and 2 percent in 2015 and 2016, respectively, compared with the current WEO baseline.

Results of the RES Flexible System of Global models imply significant spillovers from additional Russia growth shock. The impact ranges from -3 percent of GDP in Armenia to -0.1 percent of GDP in Romania. Most affected are CIS countries because of their strong trade and remittances links with Russia and, to a lesser extent, Baltic countries. The magnitude of spillovers is commensurate with existing trade links amplified by remittances from Russia in the case of Armenia, Moldova, and other CCA oil importers.

The impact of Russia's more severe recession on world GDP is deemed to be limited. The cumulative decline of world GDP for 2015-16 as a

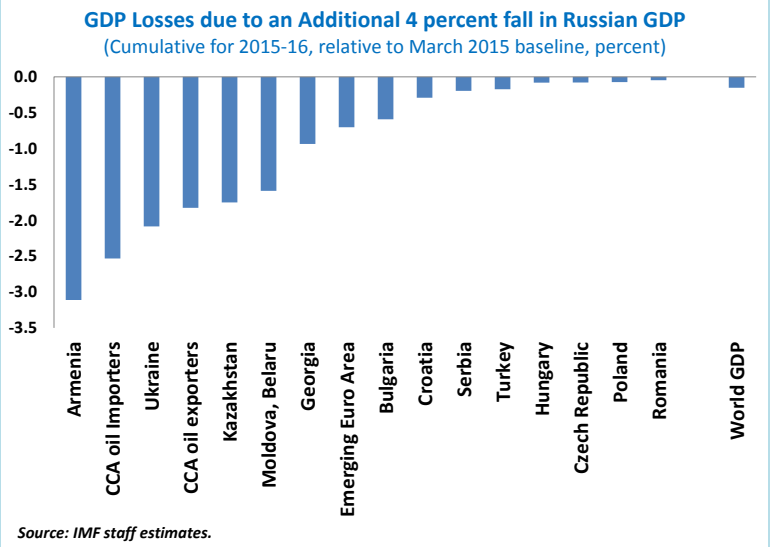
result of additional 4 percentage point recession in Russia would be about 0.2 percentage point. The main impact comes from Russia's 3 percent weight in the world GDP, since Russia's trade (excluding energy) and financial links with the rest of the world are relatively weak. 


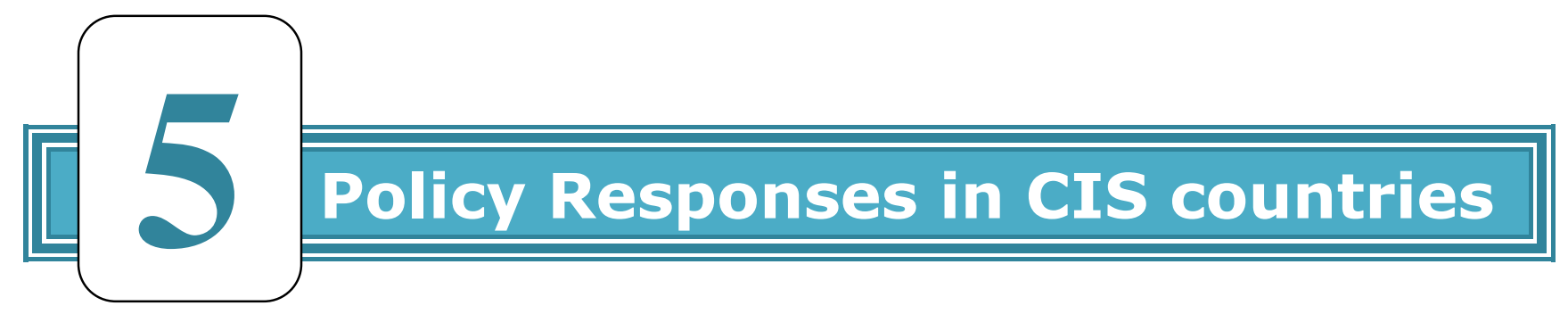

Policy responses so far have focused on mitigating the immediate consequences of spillovers. Fiscal policies were loosened in addition to allowing automatic stabilizers to work in most countries. Exchange rates were allowed to depreciate to absorb shocks and monetary policies were tightened significantly. In a number of countries, macroprudential measures were put in place to discourage further financial dollarization. Going forward, there is a need to continue strengthening policy frameworks, including improving institutional frameworks and accelerating structural reforms to bolster growth, increasing resilience to shocks, and buttressing financial stability.

In the fiscal area, many countries responded to shocks with expansionary policies in 2015, though to varying degrees (see Figure 4). In most cases, countries chose to let the automatic stabilizers work, while spending increased as a function of available fiscal space and financing.

- The fiscal policy response of energy exporters-countries with buffers-was mixed. Kazakhstan took a proactive stance, enacting a large fiscal stimulus to counteract spillovers from Russia, as well as lower oil prices. The stimulus, financed from the oil fund and multilateral developments banks could total up to 6 percent of GDP over the next 3 to 5 years and includes infrastructure spending projects as well as subsidized programs to promote small and medium enterprise (SME) lending and measures to reduce NPLs in the banking system. The government also requested $\$ 2$ billion (about 1 percent of GDP) in budget support from the World Bank and \$1 billion from the Asian Development Bank to help finance the expected larger deficit. Uzbekistan cut some taxes, including corporate income tax to stimulate economic growth. However, Turkmenistan and Azerbaijan have cut spending plans because of capacity constraints and earlier large investments.

- For energy importers with low buffers, increasing spending to support growth is conditional on securing favorable financing. Financing under IMF-supported programs allowed Armenia and the Kyrgyz Republic to implement countercyclical polices. In addition, some governments (Armenia, Tajikistan) have sought additional donor support, in particular for capital spending projects and on-lending to SMEs. Kyrgyz Republic is implementing an intensive externally financed public investment program. In 2014, Moldovan authorities introduced a 0.2 percent of GDP subsidy to the agricultural sector to shore up the affected sector in response to the import ban imposed 
by Russia on some of the Moldovan agricultural products. Some countries are also considering easing tax policy.

\section{Figure 4. Fiscal Response in CIS countries}
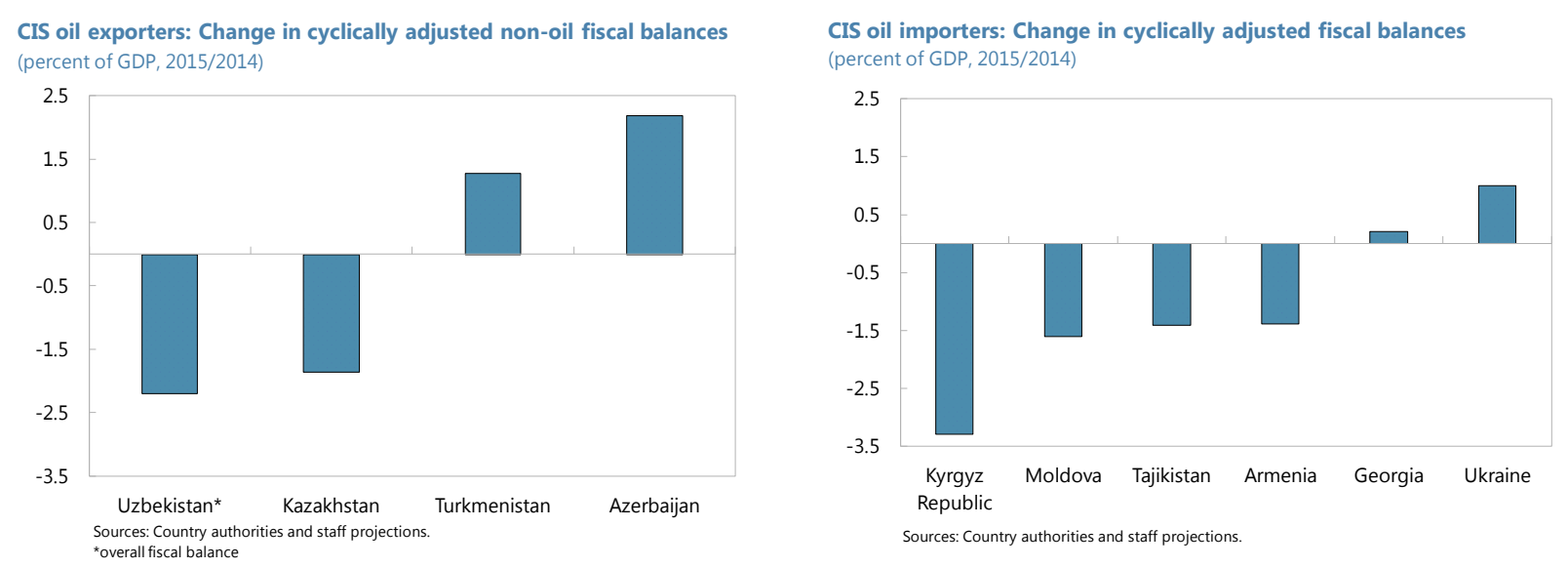

\section{Nearly all CIS countries have allowed some nominal depreciation/devaluation over the} past year or so. The policy response has involved central bank FX interventions, while allowing gradual depreciation, and three cases of step devaluation. In some countries, FX sales have reached more than 20 percent of gross reserves, and currencies continued to depreciate:

- While initially resisting exchange rate changes through interventions, CIS oil importers allowed their exchange rate to depreciate. Armenia and Tajikistan have allowed some depreciation, but sought to limit this with large FX sales. Georgia and the Kyrgyz Republic, however, have allowed their exchange rates to move with less intervention. Following an initial attempt to stave off mounting exchange rate pressures through administrative measures, the National Bank of Republic of Belarus (NBRB) has allowed substantial ruble depreciation, which amounted to 30 percent against the U.S. dollar. It also started the transition toward a more flexible exchange rate regime. Reflecting weaknesses in the banking system, political uncertainty, and spillovers from Russia, Moldova's exchange rate has depreciated by about 30 percent against the U.S. dollar.

- In contrast, most CCA oil exporters have tightly managed exchange rates and most resorted to step devaluations or move to more flexible regimes. Following the preemptive devaluation in February 2014, Kazakhstan tightly managed its tenge/dollar exchange rate before moving to the floating regime in August 2015. In response to the combined effects of ruble depreciation and falling energy prices, Turkmenistan devalued its currency by 19 percent against the dollar (January 2015), and Azerbaijan devalued the manat by 34 percent vis-à-vis the dollar (February 2015). Uzbekistan has maintained the same pace of adjustment of its crawling peg as in 2014, but the spread between official 
and parallel market exchange rate has more than doubled in 2015. In most cases, the exchange rate adjustments have been poorly communicated, thus undermining confidence in the currency.

\section{Monetary policies tightened in response to rising pressures on currencies and inflation in majority of countries. Armenia, Belarus, the Kyrgyz Republic, Moldova, and to some extent Tajikistan used a wide set of instruments to tighten monetary policy, including raising policy and other rates and mopping up excess liquidity. For example, the Central Bank of Moldova has significantly tightened monetary policy, increasing the policy rate by 1000 basis points within three months. However, given impaired interest rate transmission channels and barely positive real policy rates in some case, the effectiveness of monetary policy was limited. Uzbekistan policy has been mixed: while tightening the monetary policy by restricting growth of monetary aggregates, the authorities relaxed policy at the same time by keeping interest rates low.}

\section{In the financial sector, some countries have reacted to increased dollarization by} introducing macroprudential measures. The policy response involved increased reserve requirement for foreign currency deposits (Armenia), higher provisioning for foreign currency lending (the Kyrgyz Republic), tightening consumer lending (Azerbaijan), and reducing the share of mortgage and consumer loans in the total loan portfolio (Azerbaijan). To mitigate negative spillover to the banking system from problems in the agricultural sector, generated by Russia's import ban on Moldovan agricultural goods, the Moldovan authorities relaxed temporarily regulation for agricultural loan classification.

Looking ahead, the case for strengthening domestic policies to spur potential growth and buttress financial stability in view of the long-lasting nature of the shocks is discussed in various IMF staff reports and regional reports. 


\section{References}

Husain, Aasim M., Anna Ilyina, and Li Zeng. 2014. "Europe's Russian Connections." iMFdirect, August 1. http://blog-imfdirect.imf.org/2014/08/01/europes-russian-connections.

International Monetary Fund. 2014a. "Central, Eastern, and Southeastern Europe Regional Economic Issues Update." Washington.

—. 2014b. "Republic of Poland: 2014 Article IV Consultation—Staff Report." Washington.

_. 2014c. "Russian Federation: 2014 Article IV Consultation-Staff Report." Washington.

_ 2015a. "The Czech Republic: 2015 Article IV Consultation-Staff Report." Washington.

_. 2015b. "Hungary: 2015 Article IV Consultation-Staff Report." Washington. 